\title{
Student Management: A Philosophy OF CONTEMPORARY ISLAMiC EDUCATION
}

\author{
Sadam Fajar Shodiq \\ Department of Islamic Education, Faculty of Islamic Studies, Universitas Muhammadiyah Yogyakarta, Indonesia \\ E-mail: sadamfajarshodiq@fai.umy.ac.id
}

\begin{abstract}
The learning process in contemporary Islamic Education is more emphasized on aspects of activities undertaken by students. Education aims to explore and develop the potential of students. Lately, there are symptoms of delinquency that lead to criminal acts that the perpetrators are students in high school. The data released by the Yogyakarta Police stated that during the year 2016 there have been fights between students as many as 43 cases, even until there are victims who died. The incident is very contrary to the slogan of Yogyakarta as a student city. This study aims to analyze how the management of students at SMA Muhammadiyah 6 in Yogyakarta in dealing with various problems of students today. The qualitative approach and descriptive analysis are used to test the data of interviews, observations, and documentation. The results of this study indicate that various strategies are needed in coaching students, so the educational process will be more optimal in exploring and developing students' potential. SMA Muhammadiyah 6 Yogyakarta does not carry out the discipline of students that have been made and does not deal with violations committed by students. Student management does not run according to the rules that have been made, this is because the SMA Muhammadiyah 6 Yogyakarta lacks students. The conclusion of this study shows that the management of students at the SMA Muhammadiyah 6 Yogyakarta is currently less than optimal and there are still minimal programs that can optimize student potential.
\end{abstract}

Keywords: Student Management; Islamic Education; Philosophy

\section{INTRODUCTION}

The learning process in contemporary Islamic Education has put forward the aspect of students' activities as a priority. Education aims to delve and develop students' potentials. Lately, the sign of delinquency which leads to criminal acts committed by high school students has emerged. According to the data from DIY local police, there were 43 cases of school fights throughout 2016, in which one of them resulted in death. Such occurrences are opposing Yogyakarta's slogan as the "city of students". This research aims to analyze student management at SMA Muhammadiyah in Yogyakarta in dealing with a variety of current students' problems. SMA Muhammadiyah do not particularly implement the constituted rulings, and there are no strict punishments towards violations committed by the students. The student management does not function following the school rules, which happened because the SMA Muhammadiyah on average are in shortage of students.

SMA Muhammadiyah 6 Yogyakarta students have heterogeneous backgrounds. Some students are transfer students from other schools, the majority of students are moving because of problems in the previous school. Besides, the background of some of the SMA Muhammadiyah 6 Yogyakarta students was from a broken home family. therefore the problems arising from student behavior are very complex, then proper student management is needed.

The teacher plays an important role in planning, organizing, leading, and controlling the classroom. The teacher fosters and guides students according to various social, economic, cultural backgrounds and individual traits, helps students learn and work according to their potential and abilities Shodiq \& Syamsudin, (2019). The teacher becomes the main character in managing students. Student management is included as one of the education management substances. Student management is placed in the strategic position, because the student service center, both within the educational institution and outside the educational institution, is aimed at the students (Wilkinson \& Brooks, 2018). All academic activities, whether related to academic management, supporting academic services, human resources, financial resources, infrastructure, or school's relations to the society, are strived for the students 
to receive reliable educational services. Based on this consideration, the student management should be provided for the headmaster or future headmaster through education and training.

Student management is a regulation aimed at students at the school since they were first enrolled until their graduation, even after becoming alumni (Troisi, 2015). The study fields of the student management involve arrangements of students' activities since first enrollment until graduation (Akinloye, Adu, \& Ojo, 2017), both of them directly or indirectly: to the academic staff, educational sources, and infrastructure. Therefore, student management involves the following matters.

Included in the student planning are school census, school size, class size, and effective class (De Nobile, El Baba, \& London, 2016). Student admission comprises of the wisdom of student admission, the system of student admission, criteria of student admission, the procedure of student admission, resolution of student admission problems. The new student's orientation is consisting of the rulings of the first days of students at the school, student's orientation week, approaches used in the student's orientation, and the student's orientation techniques. Arranging attendance and absence of students at the school. Included inside are: students who skip classes, come late, and leave school before it is due. Managing the grouping of students both based on equal function and different functions. Arranging the student's evaluation, whether in improving the learning process, supervision, and counseling or in the student's promotion interest. Arranging the rate increase of students. Organizing mutated and dropped out students. Constituting code of ethics, trials, and improvement of student's discipline. Arranging student services including academic counseling and administrative service. Student supervision and counseling regulate the student's organization, including Inter-Students Organization and Alumni organization. This research aims to find out the student management, problems of student management, and solutions regarding the student management problems in SMA Muhammadiyah in Yogyakarta.

\section{MethodOLOGY}

This research was qualitative-descriptive research through a case study by bringing up an in-depth issue of a case from field research. The subjects in this study were all students and Teachers of SMA Muhammadiyah 6 Yogyakarta. The data collection was conducted through observation, interviews, and documentation. The activities in qualitative data analysis were carried out interactively and take place continuously until it is complete so that the data is saturated. The size of data saturation was characterized by no longer obtaining new data or information. Activities in the analysis include data reduction, data display, conclusion, and verification.

\section{RESULTS AND DISCUSSION}

\section{A. Results}

\section{1) Planning for New Students}

In the planning activities of new students in SMA Muhammadiyah 6 Yogyakarta include (1) analysis of student needs; (2) acceptance of new students; (3) selection of new students; (4) orientation of new students; (5) student placement; and (6) students' recording and reporting.

\section{2) Coaching and Development of Students}

From the student program that has been prepared by the school, some work programs are not following the student field such as alumni tracking and promotion. This should be a work program in the field of Public Relations that has direct relations with the community and alumni. The student field must focus more on students in the work programs that are carried out, such as competition activities, improvement of discipline, student character planting, and so on. This will have an impact on students, there is no work program related to students and can accommodate all the interests and talents of students. So the school cannot control the character of students. Besides, the student activities arranged did not experience improvement.

Besides, in the preparation of school work programs do not make a work program matrix that contains the name of the work program and the time of the program implementation. This is because the implementation of the work program has been recorded in the school education calendar, so it does not require matriculation. However, in the preparation of programs, it is necessary to have a work program matrix because it aims to monitor work programs. When will the work program be prepared and implemented? With the guidance of the work program matriculation, the vice-principal of the student field can check the time of the work program implementation, and also all tutors can find out the work program implementation by looking at the existing matriculation.

The development and development of students at the SMA Muhammadiyah 6 Yogyakarta are carried out in the learning process and extracurricular activities. This is as explained by Shodiq et al., (2019) that educational institutions (schools) in the development and development of students usually carry out activities called curricular activities and extracurricular activities.

\section{B. Discussion}

\section{1) Student Management: Unravel the common thread of educational problems}

Sociologically, students possess similarities. Such similarities can be perceived from the reality that they all are human beings, thus having identical elements of humanity. The fact shows that there is no human more humane than the others, and there is no human-less humane than the others. These similarities impacted in equal rights. Amongst the rights, there is an important right to acquire qualified educational services. 
Equal rights then conceive equal educational services through schooling. In this system, services given are accentuated to the similarities possessed by the students (Missingham \& Matthews, 2014). Education through schooling, in reality, is mass-oriented rather than the individual. The limitations in the schooling system allow more portions of similarity-based services than differencebased services.

However, these similarity-based services were then criticized. The critics were heavily related to the psychological views of humans (Missingham \& Matthews, 2014). Although humans are believed to have similarities, this could be proven different if scrutinized further. This view then displayed reassuring evidence, that there are no two or more kids who are similar. For instance, a pair of twins who could look unfailingly identical is different. Because of this difference, they need different educational services as well. Similarity-based services applied through the schooling system was then being questioned, and as the responses, different services were then inserted into the schooling system (Brodie \& Bennett, 1979).

There are two demands, which are accentuation in the similarity- and difference-based services. The accentuation conceived an idea highlighting the importance of student management. Student management is an activity aiming to organize the aforementioned two demands to be fulfilled at school.

Any services accentuated in the similarity or difference of the students, both are directed to optimize the development of students following their capabilities. As a result of differences in students' natural gifts, there will be slow-developing students and high-developing students (Yeager, 1994). Healthy competition will be possible if there are efforts and managerial activity, which are student management. Likewise, the troubled students as the result of competition can also be well-handled if the student management runs well.

In attempting to obtain self-development, many necessities often pulling each other when deciding which are the priorities. On one side, the students want to succeed in their academic achievement. On the other hand, they want to succeed in social life (Terry, 1960). Moreover, in pursuing both, they want to acquire welfare. The right choices over these three interesting aspects are not seldom triggering problems for students. Therefore, particular services with good management are needed. Student management attempts to fulfill such a necessity.

\section{2) Student Management: Efforts to optimize Student Potential}

In essence, a school has a function as: (1) a place of formal education within a certain time according to the type, level, and nature of the school, (2) a place of education and teaching according to applied curriculum, (3) a place of Inter-Students Organization (OSIS), (4) a place of students' supervision and counseling at school (Firmanto, 2017).

The problems that arise in SMA Muhammadiyah 6 Yogyakarta are varied, among others are related to the enrollment of students in which admissions are the process of data collection and services to new students entering school after they meet the requirements set by the school. In this activity, the principal needs to establish a committee for admission. In this case, the principal can use the new student enrollment guidelines issued by the Directorate General of Primary and Secondary Education. The following activities after the admission of new students are data collection.

This data is necessary to implement the supervision and counseling program if students encounter difficulties in learning, to consider student achievement, to advise the parents about student achievement, moving school, and so forth. Several other activities must be done in the new student enrollment including the determination of school capacity, the determination of the requirements for prospective students to be accepted in the school and the establishment of a new admission committee.

For this first problem, each year a new admission committee is established. The committee is assigned the task to manage and organize all admission activities. School leaders should be able to provide clear guidance to the committee so that the admission of new students can run smoothly. The new students' acceptance is one of the first school activities which is usually done by selecting the students. The management of the admissions should be done in such a way so that teaching-learning activities can be started on the first day of every new school year. In the admission of new students, the most fundamental problem is the lack of reliable strategies for obtaining a big number of students, this is due to the lack of training of marketing conducted by the schools.

Besides, schools have a great responsibility to develop the students' learning progress. This learning progress should be periodically reported to the parents. This is the responsibility of the school leader. Therefore, the leader has to know the progress of the students at the school as well as the background of the problem they may have.

The report of learning progress should not be regarded only as a routine activity, but it should have the intention to encourage parents to participate actively in fostering their children's learning process. Then, the evaluation for students should be also conducted to know the development of the students, to know the method of teaching, and to seek a solution for the students' improvement.

The problem which is also closely related to the progress of this study is the issue of student supervision. The school responsibility is not only giving knowledge and skills but also educating children to be fully human. Therefore, the school's responsibility is not only providing knowledge sharing but also guiding the students toward maturity. In this context, the task of the school leaders is to organize the counseling as well as supervision activities at schools. With this supervisory activity the students will be helped to recognize themselves; their strengths and weaknesses. Children will be helped to be able to overcome the problems that can interfere with the learning activities. It is expected that the children will be able to grow healthy both physically and spiritually and can realize their maximum potentials. 
Student supervision is a service for the students both inside and outside the class. Giving Supervision to the students can be done by creating conditions that make students aware of their tasks. In this case, the steps taken by a principal include providing orientation to the new students, organizing and recording the attendance of the students, recording the achievements and activities achieved and performed by students, and advising the students' discipline as learners at school. The problems mentioned above must be immediately solved so that the quality of the education result can be maximized.

The term student management is a combination of the word management, student, and school-based. Management itself is variedly interpreted based on the experts' points of view. Etymologically, management derives from the word 'manage' or magiare which means training horses to step their foot. The definition of management is that there are activities involving mind and action (Knezevich, 1961). Terry defines management as the accomplishing of the predetermined objective through the effort of other people (Terry, 1960). Meanwhile, Siagian defines management as an ability or skill to achieve a particular result to reach a goal (Mulyasa, 2003).

From those perspectives, it is clear that management is an activity conducted together by two or more people based on particular rules to obtain a particular goal. Due to those particular rules, there will be a manager and those who are managed by those people. The manager, during the working process, will not directly work using their own hands but other people's. On the other hand, those who are managed will directly work using their hands. During the working process, both the manager and the managed can optimally utilize the provided facilities and infrastructures.

The learners have several names such as students, learning subjects, protégés, pupils, and so forth. Those different names within this book refer to the same meaning and subject. Whatever the term is, students are those who are educated at schools or certain educational institutions. Thus, what is Student Management? Knezevich defines student management or pupil personnel administration as a service focused on regulation, supervision, and student services both inside and outside the classroom, such as introduction, registration, individual services in improving skills, interests, and needs until they are considered mature at school (Knezevich, 1961).

Student management can also be defined as the students' regulation since their enrolment until graduation. What it directly regulates is the rules concerning the indirect aspects of the students. This regulation concerning other aspects is supposed to give the best services towards the students. Student management is also defined as a whole process that is arranged and intentionally performed, as well as continuous guiding, towards all the students (within an educational institution) so that they can effectively and efficiently follow the teaching-learning process, since their enrolment until graduation (Gunawan, 1996). Further, student management is management that emphasizes on four school-based management pillars, namely quality, independence, society participation, and transparency. Therefore, all student management activities should be accentuated on those four pillars.

\section{3) Student Management: Purposes and Functions}

Student management aims to regulate various activities regarding students so that the teaching-learning process can be performed smoothly and orderly, as well as to achieve educational purposes. To achieve the purposes, student management should include four activities: first, student enrolment; second, learning improvement; third, coaching and guiding; and fourth, disciplinary guiding and monitoring (Mayfield \& Mayfield, 2017).

Specific purposes of student management are stated below:

a. Improving student's knowledge, skills, and psychomotor.

b. Conducting and improving a student's general knowledge, potentials, and interests.

c. Channelizing student's aspirations and hopes and fulfilling student's needs.

d. It is hoped, by reaching previous purposes, the students can achieve happiness and welfare in their next stage of life, and is hoped to learn optimally to achieve their dreams and goals.

In general, student management is functioned as students' tool to optimally improve themselves in several aspects, like an individual, social, aspiration, necessity, and other potentials (Grissom \& Loeb, 2011).

On the other hands, the specific functions of student management are formulated as below:

a. Functions regarding students' individuality; the students are expected to improve their potentials without too much hindrance. Those innate potentials include general knowledge, potentials and talents, and other skills.

b. Functions regarding students' social improvement; the students are expected to be able to socialize with their peers, parents and families, and their social environment at school and society. This function is related to the nature of humans where students are also social beings.

c. Functions regarding students' aspirations and hopes channelization; it is expected that the students can channelize their hobbies and interest. They are needed to be well-channelized to support overall students' selfimprovement.

d. Functions regarding students' needs and welfare fulfillment; the students are hoped to reach their welfare in the future. This is quite important for the students since they will also think about others' wellbeing.

\section{4) Student Management Principles: A step forward in developing Character}

The principle is something that should be followed in performing duties. If that something is no longer followed, then it is no longer called principle. In student management, the principles mean that, in managing the students, the rules should be followed and grasped. The principles of student management are: 
a. Student management is considered as whole school management (Goetsch \& Davis, 2016). Therefore, it should share the same and or support overall management purposes. Sectoral ambitions of student management should be placed within the school management framework. They cannot be placed outside the school system.

b. All student management activities should take on an educational mission to teach and educate the students. Any forms of activity, be it light or heavy, liked or disliked, should still be focused on educating the students.

c. Student management activities are used to unite students who come from different backgrounds and have many differences (Sunindijo, 2016). The activities should lead those differences as something that unites them, not triggering the conflicts so that they can understand and respect each other better.

d. Student management should be seen as regulation and supervision towards the students. Hence, there should be eagerness of the guide, in which the students themselves. Supervision is impossible to be well-performed if the students are reluctant to follow the process (Galanis et al., 2016).

e. Student management activities should encourage students' independence. The principle of students' independence will be useful, not only when they are at school but also when they directly join the society (Salandin, 2014). In other words, students' dependency should be gradually reduced by conducting several activities that support independence.

f. What is given to the students and is always attempted in the management should be functional towards students' life, whether in their school life or the future?

\section{5) Student Management Approach: Managing Student Potential}

There are two approaches used in student management (Yeager, 1994). The first is the quantitative approach. This approach focuses more on the administrative and bureaucratic aspects of educational institutions. In this approach, students are expected to meet the demands and expectations of educational institutions. This approach assumes that students will be mature and achieve their goals when they can obey the regulations, tasks, and expectations demanded by their institution.

In operational management, the implementation of this approach can be: requiring absolute attendance for learners at school, tightening the presences, requiring high discipline, and asking for completing the tasks assigned to students. Such an approach is indeed accentuated on the effort to improve the learners' capability.

The second is the qualitative approach. This approach concerns more about the welfare of the students. If the quantitative approach is directed to the students' potential, then this qualitative approach is directed to the students' happiness. The assumption of this approach is, if students are happy and prosperous, then they can learn well and happily. Besides, they can also develop themselves in educational institutions such as schools. This approach also emphasizes the need to provide a conducive and enjoyable learning environment for optimal self-development.

Between the two approaches, there is certainly the middle way, that is the coherent approach. In such a coherent approach, students are required to meet the bureaucratic and administrative demands of the school, but at the same time, the school should offer incentives that can provide the students' needs and welfare. In other words, students are required by the institution to complete heavy tasks, but they should be also provided a conducive atmosphere to complete them. Those provision of prosperity, conducive climate, and reliable services are to discipline the students in completing the tasks given to them.

\section{6) Solution for the Problems of Student Management}

According to the problems mentioned above, the researcher tried to provide solutions, among others:

1. The school should improve the new admission system which is started by training the teachers appointed as new admissions committees. The training can be about how to influence new students to be interested in studying at SMA Muhammadiyah 6 Yogyakarta.

2. The implementation of student management can improve learning achievement if the student activities are selfdirected as a student organization. The purpose of establishing the organizations are: (1). to provide skills, leadership, creativity, patriotism and noble personality, (2). to involve the students in the living process in a nation and state, and (3). to foster the students in the organization to develop leadership (Suprapto, 2017).

3. Schools should make more effective activities to support the development of students' potentials as well as to accommodate the aspirations of students relating to the learning process.

4. Supervision of the students should be done continuously started by the principals and the teachers.

5. Student supervision is done by providing some activities of habituation, extracurricular activities, and incidental activities. These activities are some of the selfdevelopment activities (Hufron \& Imron, 2016).

6. Using a web system for student supervision. The webbased system that uses the internet media is intended to facilitate students to complain and facilitate the class teacher, principals and teachers in handling the student complaints effectively (Leonard-Barton \& Deschamps, 1988).

7. Educate the students to be more disciplined, since basically the purpose of disciplining the students is to train them to control and direct themselves in their environment, therefore they will have a sense of responsibility and maturity for their happiness in the future life (Nurmadiah, 2014). 


\section{IV.CONCLUSION}

After conducting observations, and problematic analysis in SMA Muhammadiyah 6 Yogyakarta, it can be concluded that the problems related to student management are widely varied from student admission to student supervision. The problem should immediately have effective solutions so that the goal of education to make students a fully human will be achieved immediately.

Considering the problems mentioned above, the researcher tries to provide solutions such as: (1) The school should improve the quality of new students admission system starting from giving training to the teachers appointed as new admissions committee on how to influence new students to be interested in studying in SMA Muhammadiyah 6 Yogyakarta; (2) The implementation of student management can improve learning achievement if student activity is self-directed and self-managed by establishing student organization; (3) Supervision of students should be done continuously starting from giving good example done by the principal and teachers.

\section{REFERENCES}

Akinloye, G. M., Adu, E. O., \& Ojo, O. A. (2017). Record Keeping Management Practices and Legal Issues in the School System. The Anthropologist, 28(3), 197207. https://doi.org/10.1080/09720073.2017.1335832

Brodie, M., \& Bennett, R. (1979). Managerial Effectiveness. Management Research News. https://doi.org/10.1108/eb027741

De Nobile, J., El Baba, M., \& London, T. (2016). School leadership practices that promote effective whole school behaviour management: a study of Australian primary schools. School Leadership \& Management, 36(4), 419-434. https://doi.org/10.1080/13632434.2016.1247041

Firmanto, R. (2017). Pengaruh Manajemen Kesiswaan terhadap Disiplin Belajar dalam Mewujudkan Prestasi Belajar Siswa. Jurnal Pendidikan Universitas Garut, 11, 1-8.

Galanis, N., Mayol, E., Alier, M., \& García-Peñalvo, F. J. (2016). Supporting, evaluating and validating informal learning. A social approach. Computers in Human Behavior, 55, 596-603. https://doi.org/10.1016/j.chb.2015.08.005

Goetsch, D. L., \& Davis, S. B. (2016). Quality Management for Organizational Excellence: Introduction to Total Quality. Pearson. https://doi.org/British Library Cataloguing- In Publication data

Grissom, J. A., \& Loeb, S. (2011). Triangulating Principal Effectiveness: How Perspectives of Parents, Teachers, and Assistant Principals Identify the Central Importance of Managerial Skills. American Educational Research Journal. https://doi.org/10.3102/0002831211402663

Gunawan, A. (1996). Administrasi Sekolah: Administrasi Pendidikan Mikro. Jakarta: Rineka Cipta.
Hufron, A., \& Imron, A. (2016). Manajemen Kesiswaan Pada Sekolah Inklusi. Jurnal Pendidikan Humaniora.

Knezevich, S. J. (1961). Administration of Public Education. New York: Harper and Brothers.

Leonard-Barton, D., \& Deschamps, I. (1988). Managerial Influence in the Implementation of New Technology. Management Science. https://doi.org/10.1287/mnsc.34.10.1252

Mayfield, J., \& Mayfield, M. (2017). Leadership Communication. International Journal of Business Communication. https://doi.org/10.1177/2329488416675446

Missingham, D., \& Matthews, R. (2014). A democratic and student-centred approach to facilitating teamwork learning among first-year engineering students: A learning and teaching case study. European Journal of Engineering Education. https://doi.org/10.1080/03043797.2014.881321

Mulyasa, E. (2003). Manajemen Berbasis Sekolah, Konsep, Strategi dan Implementasi. Rosda Karya.

Nurmadiah. (2014). Konsep Manajemen Kesiswaan. AlAfkar, 3, 36-68.

Salandin, A. (2014). Student-centered Teaching: An Experience at the Building Engineering School in Valencia, Spain. Procedia - Social and Behavioral Sciences.

https://doi.org/10.1016/j.sbspro.2014.05.107

Shodiq, S. F., \& Syamsudin. (2019). Teacher identity reconstruction: Socio-anthropological study of javanese society. Cakrawala Pendidikan. https://doi.org/10.21831/cp.v38i3.26098

Shodiq, S. F., Syamsudin, Madjid, A., \& Alam, N. A. R. (2019). Towards Better Management of Private Education in Indonesia: Lessons Learned From Muhammadiyah Schools. Humanities and Social Sciences Reviews, 7(2), 146-155. https://doi.org/10.18510/hssr.2019.7215

Sunindijo, R. Y. (2016). Teaching First-year Construction Management Students: Lessons Learned from Student Satisfaction Surveys. International Journal of Construction Education and Research. https://doi.org/10.1080/15578771.2015.1121937

Suprapto, R. (2017). Pengaruh Manajemen Kesiswaan Terhadap Hasil Belajar Mata Pelajaran SKI Siswa Kelas VIII E MTsN Sambirejo Banyuwangi Tahun Pelajaran 20162017. Jurnal Darussalam; Jurnal Pendidikan, Komunikasi Dan Pemikiran Hukum Islam.

Terry, G. R. (1960). Principles of Management. Homewood: Illinois Richard D. Irwin Inc.

Troisi, J. D. (2015). Student Management Teams Increase College Students' Feelings of Autonomy in the Classroom. College Teaching, 63(2), 83-89. https://doi.org/10.1080/87567555.2015.1007913

Wilkinson, J., \& Brooks, J. S. (2018). The past, present and future of educational administration. Journal of 
Journal of Education, Teaching, and Learning

Volume 4 Number 2 September 2019. Page 314-320

p-ISSN: 2477-5924 e-ISSN: 2477-8478

Educational Administration and History, 50(1), 12. https://doi.org/10.1080/00220620.2017.1401985
Yeager, W. A. (1994). Administration and The Pupil. New York: Harper and Brothers. 